\title{
A systemic non-lytic state and local thrombolytic failure of anistreplase (anisoylated plasminogen streptokinase activator complex, APSAC) in acute myocardial infarction
}

\author{
Johan Brügemann, Jan van der Meer, Bert H Takens, Hans Hillege, Kong I Lie
}

\author{
Department of \\ Cardiology, \\ University of \\ Groningen, The \\ Netherlands \\ J Brügemann \\ L H Takens \\ $\mathrm{H}$ Hillege \\ K I Lie \\ Department of \\ Hematology, \\ University of \\ Groningen, The \\ Netherlands \\ $\mathrm{J}$ van der Meer \\ Correspondence to \\ Correspondence to \\ Department of Cardiology, \\ Thoraxcentre University \\ Hospital Groningen, \\ Hospital Groningen,
Oostersingel 59,9713 EZ \\ Groningen, The \\ Netherlands. \\ Accepted for publication \\ 31 July 1990
}

\begin{abstract}
The relation between coronary thrombolysis and coagulation variables after administration of anistreplase (anisoylated plasminogen streptokinase activator complex, APSAC) was studied in patients with an acute myocardial infarction. Fifty eight consecutive patients with acute myocardial infarction were given $30 \mathrm{U}$ of anistreplase intravenously within 4 hours of the onset of symptoms. $A$ fall in the plasma concentration fibrinogen to $<1.0 \mathrm{~g} / 190$ minutes after administration of anistreplase was considered to reflect a systemic lytic state. Coronary angiography was performed 48 hours after thrombolytic treatment. The overall patency rate was $74 \%(43 / 58)$. Patency rates were significantly different in patients with a systemic lytic $(83 \%(43 / 52))$ and a systemic non-lytic state $(0 \%(0 / 6))$. The absence of a systemic lytic state after anistreplase administration seemed to be highly predictive of the failure of coronary thrombolysis. Coagulation studies showed evidence of inhibition of anistreplase induced fibrinolytic activity which may explain the failure of thrombolytic treatment in patients with evidence of a systemic non-lytic state.
\end{abstract}

Thrombolytic drugs reduced mortality in patients with acute myocardial infarction treated within 6,12 , or even 24 hours of the onset of symptoms. ${ }^{1-3}$ When treatment was started within the first 4-6 hours after the onset of chest pain, reperfusion was shown in most of the infarct related coronary arteries. However, in up to $30-40 \%$ of the patients no reperfusion could be achieved. ${ }^{4}$ Failure of thrombolytic treatment has been reported irrespective of the drug used. ${ }^{4}$ The configuration of coronary obstruction may be an important determinant of the success of treatment, ${ }^{5}$ but inhibition of drug activity has never been ruled out.

In general, streptokinase and anistreplase (anisoylated plasminogen streptokinase activator complex, APSAC) caused comparable changes in haematological variables such as fibrinogen, plasminogen, and $\alpha_{2}$ antiplasmin during the first 24 hours after they were given. ${ }^{6}$ These changes were ascribed to systemic effects. Some patients, however, showed no substantial decrease in plasma fibrinogen after anistreplase or streptokinase administration. ${ }^{7}$ This suggests resistance to these drugs. It has been suggested that a systemic lytic state, defined as a low plasma concentration of fibrinogen after thrombolytic treatment, is a prerequisite for local thrombolytic efficacy. ${ }^{8}$

To investigate the possibility of drug resistance as an explanation for failure of thrombolytic treatment, we performed a retrospective study to assess the relation between the systemic fibrinolytic effects and the local efficacy of anistreplase in patients with acute myocardial infarction.

\section{Patients and methods}

PATIENTS

We studied 58 consecutive patients ( 47 men, 11 women), mean age 57 years (range 34-71), who presented within 4 hours of the onset of chest pain. Selection criteria for thrombolytic treatment included the presence of characteristic symptoms of myocardial infarction and $\mathrm{ST}$ segment elevation of at least $0.1 \mathrm{mV}$ in one or more of the standard leads or at least $0.2 \mathrm{mV}$ in two or more of the precordial leads in a 12 lead electrocardiogram and the presence of symptoms unresponsive to sublingual glyceryl trinitrate. We excluded patients with contraindications for thrombolytic treatment and those who had been treated with streptokinase or anistreplase within the previous 6 months.

STUDY PROTOCOL

Patients were treated with $30 \mathrm{U}$ of anistreplase (Eminase, SmithKline Beecham) administered intravenously in 4-5 minutes. Infusion with heparin (30 $000 \mathrm{U}$ in 24 hours) was started 4-6 hours after thrombolytic treatment and was continued until an adequate level of anticoagulation had been achieved with oral acenocoumarol, which was started after 48-72 hours. To assess patency of the infarct related artery, coronary angiography was performed 
48 hours (range 36-60) after the administration of anistreplase in all patients. In the first 30 consecutive patients patency was also assessed after 90 minutes (range 1 to 3 hours). Patency was documented according to the score used in the thrombolysis in myocardial infarction (TIMI) trial. ${ }^{9}$ Scores of grade 0 or 1 indicated occlusion of the infarct related vessel and grades 2 and 3 patency.

\section{COAGULATION ANALYSES}

Coagulation and fibrinolytic variables were studied immediately before and 90 minutes and 48 hours after anistreplase administration. Venous blood samples were collected on ice in a $1 / 10$ volume $3.05 \%$ trisodium citrate for measurements of fibrinogen, plasminogen, $\alpha_{2}$ antiplasmin, reptilase time, and euglobulin clot lysis time. Assays were performed immediately or plasma was stored at $-80^{\circ} \mathrm{C}$ for analysis later. Fibrinogen was measured according to the method of Clauss. ${ }^{10}$ Plasminogen and $\alpha_{2}$ antiplasmin assays were performed with a synthetic chromogenic substrate (Kabi) according to the method of Friberger et al. ${ }^{11}$ Reptilase time was determined by the method of Soria $e t$ $a^{12}$ and euglobulin clot lysis times by the method of Buckell. ${ }^{13}$ The assay for fibrinogen/ fibrin degradation products was carried out on serum collected at the times mentioned above with a latex agglutination kit (Wellcome) according to the method of Pitcher. ${ }^{14}$

A systemic lytic state was defined as a decrease of the plasma concentration of fibrinogen to below $1.0 \mathrm{~g} / 1$, measured 1.5 hours after the administration of anistreplase.

\section{STATISTICAL ANALYSIS}

Plasma concentrations of fibrinogen, plasminogen, and $\alpha_{2}$ antiplasmin were expressed as mean (SD). Statistical comparisons between

Table 1 Coagulation variables of all patients stratified according to fibrinolytic state

\begin{tabular}{|c|c|c|c|}
\hline Variable & Lytic & Non-lytic & p value $\ddagger$ \\
\hline $\begin{array}{l}\text { Fibrinogen }(\mathrm{g} / \mathrm{l}): \\
\text { Before } \\
90 \text { minutes after } \\
48 \mathrm{~h} \text { after }\end{array}$ & $\begin{array}{l}3.1(0.96) \\
0.0(0 \cdot 15)^{\star} \\
2.5(0.68)^{\star}\end{array}$ & $\begin{array}{l}2.9(0.48) \\
2 \cdot 3(0.78) \dagger \\
4 \cdot 2(0.84)\end{array}$ & $\begin{array}{l}\text { NS } \\
<0.01 \\
<0.01\end{array}$ \\
\hline $\begin{array}{l}\text { Plasminogen }(\%) \text { : } \\
\text { Before } \\
90 \text { min after } \\
48 \mathrm{~h} \text { after }\end{array}$ & $\begin{array}{l}97(18) \\
11(13)^{\star} \\
55(13)^{\star}\end{array}$ & $\begin{array}{l}104(6) \\
57(9)^{\star} \\
78(12) \dagger\end{array}$ & $\begin{array}{l}\text { NS } \\
<0.01 \\
<0.01\end{array}$ \\
\hline $\begin{array}{l}\alpha_{2} \text { antiplasmin }(\%): \\
\text { Before } \\
90 \text { min after } \\
48 \mathrm{~h} \text { after }\end{array}$ & $\begin{array}{l}93(14) \\
4(5)^{\star} \\
80(16)^{\star}\end{array}$ & $\begin{array}{l}90(12) \\
35(2) \dagger \\
99(8)\end{array}$ & $\begin{array}{l}\text { NS } \\
<0.01 \\
<0.01\end{array}$ \\
\hline $\begin{array}{l}\text { Reptilase time (s): } \\
\text { Before } \\
90 \text { min after } \\
48 \text { h after }\end{array}$ & $\begin{array}{c}19(10-27) \\
109(44-201)^{\star} \\
19(15-23)\end{array}$ & $\begin{array}{l}19(18-20) \\
24(18-31) \\
20(19-21)\end{array}$ & $\begin{array}{l}\text { NS } \\
<0 \cdot 01 \\
\text { NS }\end{array}$ \\
\hline $\begin{array}{l}\text { Euglobulin clot lysi } \\
\text { (min): } \\
\text { Before } \\
90 \mathrm{~min} \text { after } \\
\mathbf{4 8 ~} \mathrm{h} \text { after }\end{array}$ & $\begin{array}{l}>120(>120) \\
<10(<10)^{\star} \\
>120(95->120)\end{array}$ & $\begin{array}{l}>120(>120) \\
<10(<10-15) \dagger \\
>120(>120)\end{array}$ & $\begin{array}{l}\text { NS } \\
\text { NS } \\
\text { NS }\end{array}$ \\
\hline $\begin{array}{l}\text { Fibrinogen/fibrin } \\
\text { products }(\mu \mathrm{g} / 1) \text { : } \\
\text { Before } \\
90 \text { min after } \\
48 \mathrm{~h} \text { after }\end{array}$ & $\begin{aligned}<8 & (<8) \\
>256 & (<8->256)^{\star} \\
36 & (<8->256)^{\star}\end{aligned}$ & $\begin{array}{l}<8(<8) \\
<8(<8) \\
<8(<8)\end{array}$ & $\begin{array}{c}\text { degradation } \\
\text { NS } \\
<0.01 \\
<0.05\end{array}$ \\
\hline
\end{tabular}

${ }^{\star} \mathrm{p}<0.01 v$ baseline; $\nmid \mathrm{p}<0.05 v$ baseline; $\ddagger \mathrm{p}$ value for between group comparison.

Fibrinogen, plasminogen, and $\alpha_{2}$ antiplasmin expressed as mean (SD). Values of reptilase time, euglobulin clot lysis time, and fibrinogen/fibrin degradation products as median (range). patients showing a systemic lytic state and a systemic non-lytic state were performed by means of Student's $t$ test for independent samples. Comparisons within the groups were made with the paired Student's $t$ test.

Measurements of reptilase time, euglobulin clot lysis time, and fibrinogen/fibrin degradation products were expressed as median (range). Patient groups were compared by the Mann-Whitney $U / W i l c o x o n$ rank sum test. Differences within the groups were tested by the Wilcoxon matched paired signed ranks test. We used Fisher's exact test to compare the result of treatment in terms of patency and the presence of a systemic lytic state. A two tailed p value of $<0.05$ was regarded as statistically significant.

\section{Results}

\section{COAGULATION DATA}

Fifty eight patients were retrospectively classified into two groups. Fifty two showed a systemic fibrinolytic state and in six patients plasma fibrinogen concentrations did not decrease below $1.0 \mathrm{~g} / \mathrm{l}$. Initial values of fibrinogen, plasminogen, $\alpha_{2}$ antiplasmin, reptilase time, euglobulin clot lysis time, and fibrinogen/ fibrin degradation products were similar in the two groups (table 1 ).

After 90 minutes, fibrinogen, plasminogen, and $\alpha_{2}$ antiplasmin concentrations were significantly reduced in both the lytic and nonlytic groups. Mean plasma concentrations of fibrinogen in the lytic and the non-lytic groups were $0.0 \mathrm{~g} / 1$ and $2.3 \mathrm{~g} / 1$ (normal range $1 \cdot 7-3 \cdot 5$ ); of plasminogen $11 \%$ and $57 \%$ (normal range $70-130$ ); and of $\alpha_{2}$ antiplasmin $4 \%$ and $35 \%$ (normal range 90-130) respectively. These differences were statistically significant. Individual values for fibrinogen in the six nonlytic patients before and 90 minutes after treatment with anistreplase were: $3.3 v 2.7 ; 2.7$ $v 2 \cdot 3 ; 2 \cdot 4 v 1 \cdot 1 ; 3.0 v 2 \cdot 2 ; 2.4 v 1 \cdot 8$, and $3.7 v 3.6$ $\mathrm{g} / 1$ respectively. The reptilase time was considerably prolonged in the lytic group from 19 to 109 seconds but did not change in the non-lytic group (19 $v 24$ seconds). Euglobulin clot lysis time was shortened from $>120$ before to $<10$ minutes after the administration of anistreplase in both groups (normal value $>120$ minutes). Serum concentrations of fibrinogen/fibrin degradation products remained within normal ranges $(<8 \mu \mathrm{g} / \mathrm{ml})$ in the non-lytic group, whereas they were considerably increased in the lytic group (median value $>256 \mu \mathrm{g} / \mathrm{ml}$ ).

These changes declined after 48 hours. At that time mean plasma concentrations of fibrinogen, plasminogen, and $\alpha_{2}$ antiplasmin were still significantly lower in the lytic group, and, with the exception of fibrinogen, below the normal ranges. Values for reptilase time, euglobulin clot lysis time, and fibrinogen/ fibrin degradation products were normal or almost normal.

PATENCY

Ninety minutes after anistreplase administration angiography showed patency in $20(67 \%)$ 
Table 2 Relation of coagulation variables to patency of infarct related vessel 48 hours after treatment with anistreplase

\begin{tabular}{llll}
\hline & Lytic state & Non-lytic state & p value \\
\hline Patency & 43 & 0 & 0.00012 \\
Non-patency & 9 & 6 & \\
Total & 52 & 6 & \\
\hline
\end{tabular}

of 30 patients. No early reocclusion occurred in these patients. Overall patency at $\mathbf{4 8}$ hours was achieved in $43(74 \%)$ of 58 patients. The patency rate was $83 \%(43 / 52)$ in the patients showing a systemic lytic state and $0 \%(0 / 6)$ in those showing a systemic non-lytic state (table 2 ). The relation between systemic non-lytic state and non-patency of the infarct related vessel was statistically significant $(p<0.001)$.

\section{Discussion}

The predictive value of a systemic lytic state for the efficacy of thrombolytic treatment with streptokinase, urokinase, or anistreplase was the subject of several previous studies. White et al did not find that systemic haematological markers of fibrinolysis were helpful in explaining the success or failure of intracoronary thrombolysis. ${ }^{15}$ In contrast, Rothbard et al showed a close relation between a systemic lytic state and reperfusion of the infarct related vessel. ${ }^{8}$ Burket et al stated that a systemic lytic state, rather than being considered an adverse effect of treatment, might serve as a reasonable clinical goal when thrombolysis is attempted. ${ }^{16}$ Lew et al showed that high residual fibrinogen concentrations identified patients in whom thrombolytic treatment was relatively ineffective. ${ }^{17}$ It is difficult to compare the results of these studies. In the first three studies intracoronary streptokinase or urokinase was given, whereas in Lew et al's study streptokinase was administered intravenously. The dosages of streptokinase varied widely as did the interval between onset of chest pain and thrombolytic treatment. Finally, a systemic lytic state was defined differently in these studies-as a reduction in fibrinogen of at least $50 \%,{ }^{15}$ of at least $10 \%{ }^{8}$ or to below $0.5 \mathrm{~g} / 1,{ }^{17}$ and Burket et al did not define a cut off point. ${ }^{16}$ Marder et al studied 106 patients treated with streptokinase or anistreplase. ${ }^{7}$ A systemic lytic state was defined as a fall of $>20 \%$ in plasma fibrinogen concentration. In 4 of the 58 patients treated with $30 \mathrm{U}$ of anistreplase a systemic non-lytic state was found and none of these patients achieved reperfusion. None the less, no statistically significant relation between a systemic non-lytic state and failure of reperfusion was found. In the remaining 48 patients treated with a low dose of intracoronary streptokinase there was also no statistical correlation. Despite the presence of a systemic non-lytic state reperfusion occurred in 10 patients. This discrepancy was partly explained by local thrombolytic effects of intracoronary streptokinase.

In our patients we regarded a systemic lytic state as being likely if the concentration of plasma fibrinogen was $<1.0 \mathrm{~g} / 190$ minutes after the administration of anistreplase. This value was chosen because it is commonly accepted as the haemostatic concentration of fibrinogen. ${ }^{18}$ In the lytic group there was an almost complete depletion of fibrinogen, plasminogen, and $\alpha_{2}$ antiplasmin, associated with a short euglobulin clot lysis time, considerably prolonged reptilase time, and a high concentration of fibrinogen/fibrin degradation products. In both the lytic and the non-lytic patients there was a comparable shortening of the euglobulin clot lysis time. Euglobulin clot lysis time reflects the fibrinolytic activity of plasma after inhibitors have been removed. Apparently, the fibrinolytic system was activated by anistreplase in all patients. The moderate decrease in plasminogen and $\alpha_{2}$ antiplasmin in the non-lytic group also accorded with activation of the fibrinolytic system. Because neither reptilase time nor the concentration of fibrinogen/fibrin products changed, whereas the fibrinogen concentration decreased but remained within normal ranges, it seems likely that inhibition was responsible for the limited expression of fibrinolytic activity.

None of the patients in the non-lytic group showed reperfusion of the infarct related vessel. Thus fibrinolytic inhibition seems to be restricted not only in terms of systemic effects but also for local thrombolytic failure. Initial plasma concentrations of $\alpha_{2}$ antiplasmin were similar in both groups. Therefore, it is unlikely that this potent inhibitor is responsible for the supposed fibrinolytic inhibition. Anti-streptokinase antibodies from earlier treatment with streptokinase or anistreplase can be excluded because none of the patients had previously received one of these drugs. There may have been naturally occurring anti-streptokinase antibodies, ${ }^{19}$ but they were not sought in our patients.

A systemic non-lytic state 90 minutes after the administration of anistreplase in a proportion of patients with myocardial infarction predicted failure of thrombolysis. The absence of systemic and local fibrinolytic activity was probably due to fibrinolytic inhibitors. These compounds are currently under investigation. The reported findings are relevant not only to explain the mechanism of thrombolytic failure but may also have implications for clinical practice. A simple and rapid laboratory test to detect thrombolytic failure of anistreplase would lead to the option of additional treatment. We thank Beecham Research Laboratories, the Netherlands,
for providing us with the thrombolytic drug (anistreplase, for providin

1 AIMS Trial Study Group. Effect of intravenous APSAC on mortality after acute myocardial infarction: preliminary report of a placebo controlled clinical trial. Lancet 1988;i:545-9.

2 The GISSI Study Group. Effectiveness of intravenous thrombolytic treatment in acute myocardial infarction. Lancet 1986;i:397-402.

3 ISIS-2 Collaborative Group. Randomised trial of intravenous streptokinase, oral aspirin, both, or neither among 17187 cases of suspected acute myocardial infarction: ISIS-2. Lancet 1988;ii:349-60.

4 Marder VJ, Sherry S. Thrombolytic therapy: current status (first of two parts). $N$ Engl J Med 1988;318:1512-20.

5 Davies MJ. Successful and unsuccessful coronary thrombolysis. Br Heart $J$ 1989;61:381-4. 
6 Monassier JP, Hanssen M. Haematological effects of and streptokinase in patients with acute myocardial infarction, interim report of the IRS II study. Drugs $1987 ; 33$ (suppl 3):247-52.

7 Marder VJ, Kinsella PA, Brown MJ. Fibrinogen concentration and coronary artery reperfusion after intravenous anisoylated plasminogen streptokinase activator complex or intracoronary streptokinase therapy. Drugs 1987.33 (suppl 3):237-41.

8 Rothbard RL, Fitzpatrick PG, Francis CW, Caton DM, Hood WB, Marder VJ. Relationship of the lytic state to Hood WB, Marder VJ. Relationship of the lytic state to successful reperfusion with standard- and low-dose

9 TIMI Study Group. The thrombolysis in myocardial infarction (TIMI) trial: phase I findings. $N$ Engl $J$ Med 1985;312:932-6.

10 Clauss A. Gerinnungsphysiologische Schnellmethode zur Bestimmung des Fibrinogens. Acta Haematol 1957;17: 237-46.

11 Friberger P, Knös M, Gustavsson S, Aurell L, Claeson G. Methods for determination of plasmin, antiplasmin and plasminogen by means of substrate $\mathbf{2 2 5 1}$. Haemostasis 1978;7:138-45.

12 Soria J, Soria C, Yver J, Samama M. Temps de reptilase, étude de la polymerisation de la fibrin en présence de reptilase. Coagulation 1969;173:2.

13 Buckell $M$. The effect of citrate on euglobulin methods of estimating fibrinolytic activity. J Clin Pathol 1958; 11:403-5

14 Pitcher PM. The detection of fibrinogen degradation products (FDP) in serum and urine. Can $J$ Med Tech 1972;34:166-78.

15 White CW, Schwartz JL, Ferguson DW, et al. Systemic markers of fibrinolysis after unsuccessful intracoronary streptokinase thrombolysis for acute myocardial infarction. Am J Cardiol 1984;54:712-7.

16 Burket MW, Smith MR, Walsh TE, Brewster PS, Fraker TD. Relation of effectiveness of intracoronary thrombolysis in acute myocardial infarction to systemic thrombolysis in acute myocardial infarction to

17 Lew AS, Cercek B, Hod H, Shah PK, Ganz W. Usefulness of residual plasma fibrinogen after intravenous streptokinase residual plasma fibrinogen after intravenous streptokinase for predicting delay or failure of reperfusion in act
myocardial infarction. Am J Cardiol 1986;58:680-5.

18 Colman RW, Hirsh J, Marder VJ, Salzman EW. Hemostasis and thrombosis. 2nd ed. Philadelphia: Lippincott,
. Helman 1987:922.

19 Moran DM, Standring R, Lavender EA, Harris GS. Assessment of anti-streptokinase antibody levels in human sera using a microradioimmunoassay procedure. Thromb Haemost 1985;52:281-7. 